\title{
El viaje a la raíz: un nuevo modelo de crónica en tres autoras chilenas contemporáneas*
}

\author{
Federico Guzmán Rubio**
}

\section{Resumen}

A partir de la lectura de Volverse Palestina (2013) de Lina Meruane, Poste restante (2016) de Cynthia Rimsky y Destinos errantes (2016) de Andrea Jeftanovic, se propone un nuevo modelo de la crónica de viajes latinoamericana contemporánea: el viaje a la raíz. Partimos de la hipótesis de que, al narrar el viaje al lejano y difuso origen familiar de las escritoras, los tres textos se alejan de las familias textuales hasta ahora predominantes e inauguran una nueva genealogía. En este sentido, el objetivo de este trabajo es describir su poética, al contrastar sus propuestas con las características tradicionales del género. El resultado permite reflexionar acerca de la inmigración en América Latina desde una nueva óptica y confirma la maleabilidad de un género en constante cambio.

Palabras clave: crónica de viajes, literatura latinoamericana, literatura chilena.

\section{The Root Trip: A New Travel Account Model in Three Contemporary Chilean Authors}

\begin{abstract}
From reading Volverse Palestina (2013) by Lina Meruane, Poste restante (2016) by Cynthia Rimsky and Destinos errantes (2016) by Andrea Jeftanovic, we propose a new model of the Latin American travel chronicle: the trip to the root . Our hypothesis is that through the narration of the trip toward the distant and diffuse family origin of the three writers, the three accounts move away from the traditional textual families and inaugurate a new genealogy. In this sense, the purpose of this work is to describe its poetics and to contrast its proposals against the traditional characteristics of the genre. The result allows to think immigration in Latin America through a new point of view and confirms the malleability of a constantly changing genre.
\end{abstract}

Keywords: Travel account, Latin American literature, Chilean literature.

Recibido: 31/03/2019

Aceptado: 22/07/2019

Este trabajo forma parte de las investigaciones que atendieron a la convocatoria sobre "Crónica Actual” realizada por la revista Literatura y Lingüística en colaboración con el grupo de investigación de "Prensa y Literatura" de la Universidad Academia de Humanismo Cristiano.

** Mexicano. Doctor en Literatura Europea de la Universidad Autónoma de Madrid. Académico del Instituto Tecnológico Autónomo de México. federico.guzman@itam.mx 


\section{Introducción}

Uno de los rasgos fundamentales de la crónica en general y de la crónica de viajes en particular es su gran adaptabilidad a diferentes épocas, la que no obstante es en realidad inevitable, pues la crónica más que conformar poéticas que posteriormente se trasladan a una época con sus temáticas, soportes, ideologías y sistemas literarios específicos, opera exactamente al revés: son las temáticas, los soportes, las ideologías y los sistemas literarios los que condicionan la gestación de la crónica. Por supuesto, esta capacidad de adaptación también responde al atributo más mencionado cuando se describe el estatuto genérico de la crónica: la hibridez. A propósito de este concepto, es necesario señalar que para un género literario que se caracteriza por rebasar las fronteras de lo literario con el fin de expandirse y apropiarse de otros ámbitos y discursos (el periodístico, el político, el ideológico), traspasa la simple combinación de géneros textuales para articular realidades más amplias. En el caso de la crónica, habría que entender la hibridez como la concibe García Canclini (2013), es decir, como una combinación de "procesos socioculturales en los que estructuras o prácticas discretas, que existían en forma separada, se combinan para generar nuevas estructuras, objetos y prácticas" (14).

Esto es precisamente lo que ocurre de forma análoga con los tres textos que se analizan en el presente trabajo: Volverse Palestina de Lina Meruane (2013), Poste restante de Cynthia Rimsky (2016) y Destinos errantes (2016) de Andrea Jeftanovic ${ }^{1}$. Los tres trabajos retoman características de la crónica de viajes más tradicional para subvertirlos, cada uno a su manera (por ejemplo, mediante la originalidad en el empleo de los paratextos o la descripción de los lugares recorridos supeditada a la historia personal, y no a la inversa), al tiempo que dialogan con poéticas contemporáneas que exceden a la crónica (como el auge de la autobiografía, presente incluso en géneros en principio ficcionales como la novela, pues las tres autoras son mucho más que meros testigos de lo que observan),

\footnotetext{
De los tres libros existen varias ediciones. Para el presente trabajo se decidió trabajar con la primera edición de Volverse Palestina, porque las ediciones posteriores (publicadas por Literatura Random House en España y Argentina) incorporan en el libro el ensayo "Volverse otros" que, al tratarse rigurosamente de un ensayo en el que Meruane lee críticamente a varios autores que han escrito sobre el conflicto árabe-israelí, no es de interés para este trabajo, centrado en la crónica. En el caso de Poste restante, se decidió trabajar con la segunda edición, porque incorpora materiales paratextuales aparecidos en la primera edición (de 2002), lo que produce un interesante diálogo entre memoria, escritura y viaje. Por último, el caso de Destinos errantes es menos problemático, pues las ediciones española y chilena no presentan diferencias sustanciales.
} 
analizan conflictos internacionales desde un punto de vista íntimo y no meramente periodístico, y brindan una respuesta personal a los procesos de globalización. Todos estos elementos, probablemente sumados al hecho de que los tres libros hayan sido escritos por mujeres, dan como resultado una familia textual novedosa, con una poética bien establecida, que definiremos a lo largo del presente trabajo y que provisoriamente podríamos denominar como la crónica de viajes a la raíz.

Meruane, Rimsky y Jeftanovic, todas nacidas en Santiago de Chile entre 1962 y 1970, cuentan el viaje que, por diferentes motivos, las llevó a las tierras de sus antepasados, inmigrantes europeos que abandonaron un difuso poblado de Palestina, Ucrania y Yugoslavia ${ }^{2}$, respectivamente. Al buscar más una geografía sentimental que una física, los destinos son inciertos y a veces ni siquiera responden a un punto específico del mapa; de hecho, su destino - conformado por el cruce entre viejas historias familiares y grandes relatos culturales - es más bien legendario, pues además de tratarse de un lugar que ya no existe y que quién sabe si existió alguna vez, está ubicado en una temporalidad perdida para siempre. Pero todos estos cúmulos de incertidumbres encajan de una manera misteriosa con la realidad que las viajeras observan y viven, mientras que simultáneamente, son negados por esta. Este proceso paradójico no representa ninguna sorpresa para ellas, pues más que un descubrimiento, el propósito último del viaje es una reconciliación con sus orígenes y con una identidad que ya no aspira a ser tal, o que cada vez se reconoce más como múltiple, imposible de encasillar en una sola bandera.

Pero antes de emprender el análisis de los textos con el objetivo último de establecer sus paralelismos para estructurar la poética que, involuntariamente, los tres conforman, resulta pertinente hacer algunas aclaraciones sobre el género literario en el que se inscriben. Los tres bien pueden denominarse indistintamente crónicas de viajes y relatos de viaje. En nuestra opinión, como hemos expresado en otros trabajos (Guzmán Rubio, “Tipología del relato..." 122), la crónica de viajes es un subgénero del relato de viajes, el cual puede manifestarse también en otros formatos, como los diarios, las cartas o el relato de viajes híbrido. La crónica de viajes que, entre otras características se definiría por su

La mitad de la familia de Jeftanovic se considera serbia y la otra mitad croata, aunque ella parece reconocerse a veces bosnia o mucho más generalmente como balcánica, en lo que bien puede verse como un juego poco inocente sobre el concepto de identidad. 
brevedad y, en principio, por narrar una escena limitada a un espacio o un tiempo, es susceptible se recopilarse en un volumen que, de esta forma, daría cuenta de un periplo más amplio, como ejemplifican a la perfección algunos textos canónicos modernistas como En el país del sol, de José Juan Tablada, o España contemporánea, de Rubén Darío. La maleabilidad intrínseca al género también permite recopilar crónicas bajo el único denominador común de su autoría - que lleva implícito, además de un estilo y un punto de vista, la continuidad de la triada autor-narrador-protagonista, presente en todo pacto autobiográfico-, sin que exista una continuidad espacial o temporal, tal como sucede en libros ya también canónicos del género como Larga distancia, de Martín Caparrós, o Viajes a la América ignota, de Jorge Ibargüengoitia. En el presente trabajo, entonces, se optó por el término "crónica de viajes" por ser el subgénero al que los tres textos pertenecen: Destinos errantes es una recopilación de crónicas de diferentes viajes emprendidos y escritos por Jeftanovic ${ }^{3}$, mientras que Volverse Palestina y Poste restante, a pesar de también estar constituidos por fragmentos que bien pueden leerse independientemente, son proyectos más unitarios, que también pueden denominarse crónicas.

Por último, es necesario, aunque sea de forma superficial - pues no es el objetivo de este trabajo-, contextualizar los escritos de acuerdo con el lugar que ocupan en la historia literaria. Las tres obras que se analizan fueron seleccionadas por la forma en que tratan la crónica y por los asuntos que abordan a través de la crónica, es decir, por su poética frente a un género literario especialmente versátil. Por supuesto, la indagación para seleccionar este breve corpus se llevó a cabo dentro de la crónica de viajes latinoamericana contemporánea, pero lo que resultó una casualidad es que los tres hayan sido escritos por mujeres chilenas. Si bien este hecho, al no ser resultado de una muestra representativa, no puede servir para establecer una hipótesis relacionada con las literaturas nacionales o con la escritura de mujeres, sí obliga a hacer algunas precisiones.

Hasta donde tenemos noticia, si bien existen estudios acerca de algunos aspectos puntuales (Brintrup, “El libro móvil...” 1993; Pérez

Para los propósitos del presente trabajo, la crónica más interesante del libro y de la que se extrajo la mayoría de las citas es la que encabeza el volumen: "Sarajevo underground". No obstante, se decidió incluir en el corpus al libro como conjunto, porque en él hay referencias constantes a asuntos aquí tratados, como el origen yugoslavo y judío de la autora. 
Villalón, "Variaciones sobre el..." 2004); Casini, "Luis Sepúlveda..." 2004; Galgani Muñoz, "Paseo escritural..." 2018), la literatura de viajes factual chilena no ha sido estudiada en conjunto, a pesar de que sin lugar a dudas existe un corpus continuo desde el siglo XIX hasta el día de hoy. En un rápido repaso, podrían mencionarse como fundadores del relato de viajes literario del Chile independiente a Vicuña Mackenna (como estrategia de poder, según Brangier Peñailillo, “Construcción de...” 2012) y a José Victorino Lastarria con sus Páginas de mi diario durante los tres años de viaje 1853-54-55 y Cartas de Lima, respectivamente. Ya en el siglo XX, destacan Inés Echeverría con Hacia el Oriente (recuerdos de una peregrinación a la Tierra Santa) y el posmodernista Augusto d'Halmar con Nirvana (Viajes al extremo Oriente) y Mi otro yo; Manuel Rojas, con libros de viajes nacionales (A pie por Chile), latinoamericanos (Pasé por México un día) o exóticos (Viaje al país de los profetas); Joaquín Edwards Bello con sus crónicas de la Primera Guerra Mundial, o el escritor y diplomático Moral Lynch, quien acogió en la embajada de Chile en España a cientos de refugiados de ambos bandos, y dejó un riquísimo testimonio de su paso por Madrid en libros como En España con Federico García Lorca. Páginas de un diario íntimo, 1929-1936 o en los Informes diplomáticos y diarios de la Guerra Civil. En la conformación de un corpus viajero de la literatura chilena, también tendrían que considerarse los numerosos relatos de viajes dispersos en la obra de algunos de los escritores más estudiados, como es el caso de la correspondencia de Gabriela Mistral, los diarios de José Donoso o las páginas autobiográficas de Pablo Neruda. Y ya en el presente siglo, las obras nómadas se multiplican en las crónicas de Rafael Gumucio, Juan Pablo Meneses o Patricio Fernández.

A pesar de que los criterios para la selección del breve corpus no tomaron en cuenta aspectos de género, no puede pasarse por alto el hecho de que los tres libros analizados hayan sido escritos por mujeres. Este hecho constituye una anomalía dentro de la historia del relato de viajes latinoamericano, pues si las mujeres siempre han estado marginadas del canon literario, su situación en este género literario ha sido tradicionalmente aún más residual. Esta exclusión se debe a que a la discriminación impuesta a las mujeres en el sistema de publicaciones debe añadirse que el viaje - ya fuera con propósitos literarios, culturales, comerciales, políticos o periodísticos- ha sido una actividad predominantemente masculina. Por ello, los ejemplos de relatos de viajes latinoamericanos escritos por mujeres son una rareza, y los ejemplos 
canónicos son unos cuantos, como el Diario de una caraqueña por el Lejano Oriente, de Teresa de la Parra, o las Memorias de España, 1937, de Elena Garro, al que podría agregarse el ya citado libro de la chilena Inés Echeverría, quien define una voz lírica mediante el discurso orientalista (Ramírez Errázuriz, “Orientalismo y...” 2017). Por fortuna, en el presente siglo esta situación tiende a una mayor equidad, como lo evidencian los tres textos abordados en el presente trabajo.

No cabe duda, pues, que nos encontramos frente a una nueva transformación de la crónica. Como advierte Poblete Alday (2016) "los cambios operados desde la globalización y las nuevas tecnologías obligan tanto a repensar la función de la crónica y del cronista en nuestras sociedades latinoamericanas, como a analizar las trasformaciones observadas en el propio tejido textual" ("Hibridez y..." 189). Los tres textos que a continuación se analizan, si bien dialogan explícitamente con la tradición literaria de la que se saben herederos, son conscientes de que proponen un planteamiento nuevo que, paradójicamente, consiste en volver la vista atrás y emprender un imposible viaje geográfico hacia el pasado.

\section{La raíz del viaje}

Como siempre sucede en el género, el viaje va de la mano de la búsqueda de conocimiento o información pero, en este caso, la inspiración epistémica responde en principio a una inquietud individual, y solo en un segundo plano, a una preocupación social compartida. Los ejemplos en que los escritores viajan para convertirse en mediadores de información son muchos: Gómez Carrillo o Edwards Bello fungieron como cronistas de guerra para satisfacer la demanda de noticias de actualidad de la sociedad latinoamericana; Darío y Nervo fueron corresponsales en París o Madrid de los periódicos latinoamericanos más importantes de su tiempo solo para mantener a los lectores actualizados de las últimas tendencias de las artes, la moda y la sociedad europea; Sergio Pitol viaja a Rusia y a la Europa comunista para aprender sus lenguas y aprehender su cultura, y acaba convirtiéndose en un traductor importante de esas literaturas al español. Cabría aclarar, en el caso de Pitol, que si bien sus crónicas cumplen con una función descriptiva, esta aparece distorsionada o enriquecida por la mirada singular del autor. Pitol, —en un juego autoficcional y metaliterario-, carnavaliza toda la realidad que observa, 
lo que acerca sus textos factuales a sus ficciones más representativas, como Domar a la divina garza.

A diferencia de todos estos casos, las tres viajeras chilenas no se trasladan para satisfacer ninguna necesidad social, no son enviadas por ningún medio de comunicación y ni siquiera pretenden aprender alguna materia que dote de un motivo utilitario al tránsito; ellas viajan para confirmar o para desmentir un mito fundacional, pero no colectivo, como sí hicieron involuntariamente el padre Servando Teresa de Miery, con plena conciencia, Sarmiento. Ellas viajan para averiguar algo - no saben exactamente qué- relacionado con su origen familiar; quizás el motivo por el que sus antepasados abandonaron su lugar de origen, o quizás para hallar, del otro lado del mundo, algún vestigio que todavía las conecte con esa tierra, o alguna señal que establezca vasos comunicantes entre el territorio del pasado y del presente.

Podría pensarse que esta clase de viaje sería frecuente en ciertos países latinoamericanos en los que la inmigración es una experiencia masiva y relativamente reciente, tal como sucede en particular en Argentina, Uruguay y Chile. No obstante, esta clase de viaje, en caso de haber aparecido anteriormente, lo ha hecho de manera aislada y de ninguna forma había establecido una ruta cultural como el viaje revolucionario, tan practicado en la literatura argentina (García 2015; Saítta 2007), o el artístico, transversal a todas las literaturas latinoamericanas ${ }^{4}$. En todo caso, a pesar de no contar con antecedentes claros, las tres autoras comparten el mismo disparador - del viaje, en primer término, y finalmente de la escritura-, como si siguieran una poética preestablecida, cuando en realidad la están creando. Las tres parten motivadas por las leyendas familiares de las cuales son descendientes involuntarias. Quien tiene más clara su conexión con los países desconocidos de donde procede es Jeftanovic, quien creció escuchando historias de Yugoslavia, a grado tal que esos territorios míticos se acabaron fundiendo con el Santiago real:

El viaje analizado en el presente trabajo, con destinos tan lejanos y ajenos a la cultura latinoamericana, también puede contraponerse con el viaje interior, tan habitual en la crónica latinoamericana contemporánea, como lo señala Lindsay (2016) en su reciente estudio: "Latinoamérica es un sitio especialmente atractivo para este tipo de viajes, allí, las vastas superficies, la abigarrada geografía que se percibe al traspasar los límites de sus ciudades-estado, e incluso el interior de ellas, así como una arraigada tradición de identidades nacionales y regionales, hacen que los territorios nacionales no sean siempre, ni mucho menos necesariamente, bien conocidos, ni familiares para el viajero de la región, quien muchas veces ni siquiera los considerará propios”. (31). 
Visito Sarajevo desde hace años, cuando los hombres de la familia brindaban con Šljivovica en la sobremesa, en la que prometían "el próximo año en Yugoslavia". Sarajevo era una tierra prometida, el destino que nos jurábamos en cada fiesta con ese licor cristalino serbio, hecho a base de aguardiente y ciruelas. El brindis motivaba decenas de choques de copas antes de que el alcohol subiera a la cabeza de los adultos, cargado de recuerdos vívidos de una infancia alrededor del río Drina, del río Sava y del río Miljacka, que se fundían con el Río Mapocho y se hacían navegables. $\mathrm{O}$ bien, el recorrido por la avenida Ulica Marsala Tita, diluida en la Alameda Bernardo O'Higgins, amplias vías en las que había tráfico en ambos sentidos. San Sabas, el patrón familiar de Serbia, aparecía descendiendo de la cordillera de los Andes y de pie en la mitad del monumento a la batalla de Chacabuco. (23)

El disparador de Meruane y de Rimsky, si bien también va de la mano de las historias familiares es aún más parecido, pues ambos viajes parecen surgir de señales aleatorias del destino, de gestos inesperados, casi de una fantasía más imaginaria que de un indicio concreto. Rimsky pasea por un "mercado persa" y encuentra un viejo álbum de fotografías, de origen europeo, en el que aparecía una frase en un idioma desconocido en la que sin embargo reconoció el apellido "Rimski". La ortografía no coincide plenamente con su apellido, pero ella lo interpreta como un caso más en el que, al cruzar la frontera chilena y registrarse en una lengua desconocida e incluso en un alfabeto distinto, los apellidos de los inmigrantes se modificaban según el mal oído del funcionario de aduanas. De su familia no sabe casi nada, pues "ignora si sus abuelos prefirieron convertir su pasado en algo desconocido o sus padres no mostraron interés en conocerlo" (12); no obstante, al menos sabe que su familia materna procede de Ucrania, que su abuela nació en el barco y que algunos parientes, de los que jamás se supo nada, se quedaron allá, del otro lado del mar, a merced de los pogromos, primero, y después del nazismo y del estalinismo. Esta información vaga, mezclada con el azaroso álbum de recuerdos quizás propio - aunque muy probablemente ajeno-, le sirve a la autora para decidirse a partir al oriente de Europa en busca de alguna pista de sus orígenes.

La excusa para el viaje de Meruane es igualmente aleatoria: en Nueva York, donde reside, dos veces coincide con el mismo taxista palestino, 
que la insta a visitar la tierra de sus antepasados. Lo primero que la escritora hace es buscar algún rastro de su genealogía en Internet, pero la red, extrañamente, parece no tener nada que decir, lo que justifica aún más el viaje:

Empiezo por escribir la palabra Meruane. Oprimo la lupa que inicia la búsqueda en una base de datos. El único resultado que me devuelve la pantalla es un artículo publicado en una revista británica. 'Sahara en 1915': así se titula. Imagino [...] Se citan seis oasis algerianos y cauces de ríos deshidratados, trozos desolados de desierto, trechos de costra salmuera. Líneas más abajo aparece por fin la palabra. Meruane: otro lago salado y seco que no debe importar o ha sido olvidado. (14)

El viaje que Meruane nunca había contemplado ni siquiera como una posibilidad, se le empieza a revelar como ineludible. Ella lo posterga y lo deja a la suerte, por ejemplo, al condicionarlo a recibir una invitación para asistir a un acto literario a Europa, desde donde le sería más fácil trasladarse a Israel y Palestina. Curiosamente, en vez de una partida hacia un lugar que no conoce, Meruane (27) empieza a concebir el viaje como un regreso: "No es regresar pero la idea del viaje aparece con ese verbo a cuestas. Ese verbo y todos sus sinónimos empiezan a abrirse espacio a codazos. Una sucesión de eventos fortuitos me empuja en dirección palestina".

A diferencia de lo que sucede con otros viajes literarios, que se inspiran en rutas literarias establecidas o en obras concretas ${ }^{5}$, la excusa del viaje al origen es el simple deseo de explorar el pasado familiar. No existe la intención de apropiarse ni de integrarse a determinada tradición literaria, sino que el gesto nómada responde a la investigación más bien hipotética de una incógnita de carácter personal.

\section{La leyenda familiar}

El resultado del viaje de las tres escritoras es distinto: Meruane incluso charla con un par de parientes y nunca duda sobre la geografía de sus orígenes (aunque algunas veces se trate de pueblos arrasados por la ocu-

Los casos son abundantes y claros; por ejemplo, el viaje a Oriente a los románticos, diseccionado por Said e imitado por los viajes hispanoamericanos, el viaje ilustrado a Italia o el viaje a Extremo Oriente. En la tradición latinoamericana, el viaje modernista a París sin duda se vio condicionado por Escenas de la vida bohemia, de Henri Murger. 
pación israelí); Jeftanovic también sabe lo que busca y dónde encontrarlo, pero no se reconoce en ninguno de esos espacios supuestamente familiares; Rimsky, por último, jamás encuentra el mínimo rastro cierto que pudiera tener alguna relación con ella, pero le basta atestiguar el mundo del que probablemente partieron sus antepasados. Más allá de estas diferencias, las tres experimentan el mismo proceso de extrañamiento y de reconocimiento, como si la tierra de sus antepasados las expulsara al tiempo que les da la bienvenida.

Este proceso, en realidad, no es tan distinto del que vivieron los viajeros guiados por la literatura; los modernistas, al buscar en el Barrio Latino la vida bohemia de la que tanto habían leído y al buscar a los admirados Verlaine o Moréas, se decepcionan profundamente, aunque finalmente sí vivirán la vida bohemia que tanto habían soñado y encontrarán unos más que otros - la gloria literaria que tanto buscaban. Así, como los modernistas y tantos otros viajeros mezclaron en sus escritos la realidad de lo que veían con las expectativas de lo que creían encontrar, las tres viajeras imaginan que lo que observan se corresponde con su paisaje familiar, como cuando Rimsky describe un pueblo ucraniano en el que quizás alguna vez vivieron sus antepasados: "Ulanov es una calle sinuosa, sombreada por altos guindos, que bordea un ancho río como el del Cajón del Maipo. Cuántos recuerdos debía despertar en tu padre cada vez que atravesaba el río Mapocho. Por eso cuando compró la casa de Maruri plantó un guindo". (185).

Jeftanovic (27), por su parte, al entrar en Bosnia, espera encontrar algún gesto de familiaridad con sus supuestos compatriotas, pero este no llega: "En la frontera, un par de soldados desdentados se rieron de mi pasaporte; yo busqué en ellos algún reconocimiento tribal y solo sentí rechazo ajeno". Más adelante, mientras recorre el túnel mediante el cual la ciudad mantuvo contacto con el exterior durante el sitio, la escritora, al conversar con el guía, comprueba cuán inevitablemente se ha alejado de su origen, como lo atestigua el extrañamiento frente a las palabras, tanto escritas como pronunciadas, de ese idioma que alguna vez hablaron sus ancestros pero que para ella es desconocido:

Edis me pidió que escribiera mi nombre en un papel porque no comprendía mi pronunciación. Anoté las dieciséis letras del apellido y él puso su dedo sobre la 'c' final, queriendo comprobar mi escritura. Claro, faltaba la tilde en esa 'c', costumbre que fui perdiendo con la escritura en el computador (Jeftanovic 35). 
Con todo y que Meruane es la que sigue rastros más precisos e incluso visita a un par de parientes, quienes la reconocen como familia, también se ve sometida a la duda cuando una tía lejana le comenta que, por caprichos del árbol genealógico, es dudoso que realmente su apellido legítimo sea el de Meruane: “Algo se revuelve en mi cabeza. Algo se viene abajo. Si yo no soy Meruane entonces esta mujer que dice ser mi pariente no es nada mío. Pero hay algo aun peor: si nosotros no somos Meruane, entonces, quién soy yo" (52).

En todo momento, las tres viajeras son plenamente conscientes de que recorren terrenos más ficticios que reales; de hecho, cuando se enfrentan a la búsqueda de un dato concreto, lo más frecuente es que no encuentren nada. Sin ir más lejos, las pesquisas de Rimsky no pueden resultar más desalentadoras: en Ucrania no encuentra a ningún pariente y ni siquiera sabe si los pequeños pueblos que visita son los de sus ancestros, y antes de ello, en Israel, a donde emigró un gran número de judíos rusos, tampoco tiene mejor suerte. En el Departamento de Estudios Ucranianos de la Universidad de Tel-Aviv no encuentra pistas sobre su familia. Su última esperanza es el Museo de la Diáspora, en el que "bajo la luz melancólica que envuelve el camino, el barco, la maleta, el pasaporte, hay un servicio computacional donde los visitantes se informan acerca de su árbol genealógico" (36). Sin embargo, al escribir sus apellidos en un papel, las únicas palabras que recibe de la funcionaria son un lacónico "lo siento".

El caso de Jeftanovic es todavía más dramático, pues ella busca, de hecho, un país que ya no existe como tal: Yugoslavia. La mitad de su familia paterna se consideraba serbia y la otra mitad croata, aunque toda la rama procedía de Bosnia. En realidad, los Jeftanovic siempre se consideraron yugoslavos, sin importar que resultara imposible encasillar la identidad de ese país hasta cierto punto inventado, pues como ellos mismos bromeaban, en realidad estaba formado por "seis repúblicas, cinco naciones, cuatro idiomas, tres religiones, dos alfabetos y un partido" (40). Cuando la escritora al fin llega a la tierra de la que tanto había escuchado hablar, esta ya no existía de manera oficial, lo que enfatiza el carácter imaginario e imposible del viaje, paradójicamente real:

Cuando por fin pude viajar a Yugoslavia, Yugoslavia ya no existía. Llegué a Sarajevo buscando recorrer las direcciones familiares: un departamento en un tercer piso en una calle transitada, una fábrica artesanal de ladrillos, un hotel en el casco 
antiguo de la ciudad; propiedades confiscadas por el régimen de Tito. Más que un deseo de reivindicación patrimonial, me movía un recorrido emocional. (Jeftanovic 41)

Por si fuera poco, algunos años antes, la escritora y su familia yugoslava habían sido expulsadas del único vínculo oficial que mantenían con su tierra de origen:

El día 25 de junio de 1995, el Parlamento croata (Hrvatski Drazvni Sabor) proclamaba la separación croata de Yugoslavia y declaraba su independencia y soberanía. A quince mil quilómetros de distancia, el Estadio Yugoslavo, ubicado en la comuna de Vitacura, se reinauguraba como Estadio Croata. Fueron expulsados el cinco por ciento de los serbios, entre los cuales estábamos nosotros. Éramos socios desde hacía treinta años. (Jeftanovic 45)

La realidad, en su caso, parece esforzarse por convertir el destino del viaje en legendario, transformándolo en una posesión que no se puede sustraer y en una relación de pertenencia que, gracias a situarse en la intimidad y no en la esfera de lo burocrático, ya no se puede romper. Paradójicamente, mientras mayor es la brecha entre Yugoslavia y Jeftanovic, más se refuerza la asociación sentimental. En un género literario cuyo compromiso con lo real es una condición básica del pacto de lectura, los afectos y la imaginación cobran un protagonismo inusitado. Esto no significa que los textos deriven hacia lo ficcional sino que, por el contrario, lo imaginario cobra estatuto de realidad.

Por otra parte, aunque se alejen de ella, las crónicas no renuncian a la vocación periodística con la que nació el género. Sin pretenderlo, los tres libros trasmiten una mirada de las ciudades y países que se recorren, y son un valioso documento, por ejemplo, respecto de la guerra de los Balcanes o del conflicto árabe-israelí. Que se privilegie la intimidad y la búsqueda familiar no significa que se borre el espacio, sino muy al contrario: este se reconfigura por las historias personales y de esta forma se construye un nuevo diálogo. Al respecto, al estudiar la crónica literarioperiodística chilena contemporánea, Poblete Alday ("La crónica...") percibe la tendencia a incorporar al género las narrativas del yo, lo que crea una nueva forma de hibridez que

conjuga espacios y estrategias de enunciación; modalidades textuales canónicas y productos de la cultura de masas; subjeti- 
vidades múltiples que concurren en los distintos momentos de producción y lectura del texto; y, sobre todo, la activación conjunta de horizontes de expectativas provenientes de distintos registros textuales. Con ello - más allá del narcisismo que por esta vía se puede, o no, traslucir - la crónica nos confronta con la movilidad de las fronteras entre lo público y lo privado, en cuyo vaivén se va constituyendo lo íntimo, que por lo mismo, ya no equivale - como en la época de la crónica modernista - a lo verdadero, ni tampoco a lo auténtico. (167)

\section{El viaje a la raíz}

Casi todos los viajeros, al describir el territorio del que se habían documentado, enfatizan el quiebre que surge entre sus expectativas y la realidad, o entre el paisaje que habían construido en su mente mediante lecturas y evocaciones y el que observan sus ojos. En este caso, como las tres escritoras buscan cualquier cosa menos la realidad, sucede lógicamente lo contrario: "Una mezcla de reserva y respeto impide prolongar la observación el tiempo necesario, hambriento de imágenes fugaces se le hace necesario completarlas con la imaginación", comenta Rimsky (29) sobre ella misma, en un paseo por Tel-Aviv, en tercera persona. Porque en el relato de Rimsky las personas gramaticales varían y se alternan. Esta técnica, empleada con naturalidad, hace que el lector esté plenamente consciente de que se encuentra frente a una construcción literaria en la que se salta de lo íntimo a la descripción más genérica, siempre desde el punto de vista de un "yo" que se sabe también un "él”, es decir, un personaje.

A medida que el viaje de Rimsky avanza, su identidad, que supuestamente se iba a ver afianzada al encontrarse con sus raíces, se diluye. Además, si el propósito del viaje era el de escribir un libro, este pasa a segundo plano y se olvida porque, de hecho, Rimsky deja de ser la misma persona que salió de Chile: "Ha dejado de preocuparle la seguridad, el dinero, la máquina fotográfica, ha comenzado a olvidar que es una periodista chilena que vino a escribir un reportaje" (63). A la escritora chilena le queda pronto claro que en su viaje por Europa y Medio Oriente no encontrará pistas de su origen, sin embargo, cualquier indicio que decida tomar como auténtico, sin importar que no lo sea, o mejor, si de preferencia no lo es, terminará siéndolo, pues las identidades 
se construyen pero también se eligen. En un pasaje muy significativo, Rimsky observa cómo los turistas compran souvenirs evidentemente falsos y baratos, recuerdos, finalmente, equiparables con el álbum de fotos en el que ella creyó reconocerse en un "mercado persa" de Santiago. De esta forma, en el viaje, el círculo se cierra: la falsedad de lo auténtico queda al descubierto, mientras que el pastiche, con el tiempo y gracias a la voluntad de los viajeros, terminará ocupando un lugar de privilegio:

[...] pudo comprobar cómo los turistas, por cansancio o necesidad de volver con regalos, compran las baratijas que luego exhibirán en las repisas de sus casas en Oregon, Temuco, Guayaquil, Alaska, Pekín... Con el paso del tiempo, la muerte y las mudanzas, los objetos llegarán al mercado persa, donde serán encontrados por sus hijos o nietos, quienes asociarán las baratijas al relato mítico, volverán a comprarlas y la réplica tomará el lugar del original. (106)

En Meruane, la imaginación ocupa un lugar igual de determinante. Para no ir más lejos, el mismo viaje es una consecuencia de la imaginación pues, al reencontrarse con el taxista palestino que la insta a partir, cuando este le pregunta cuándo viajará a la tierra de sus antepasados, ella le responde: "En marzo, le digo por decir cualquier cosa, y aunque no tengo fondos para ese viaje empiezo a imaginar que lo que digo es cierto" (30). El futuro viaje, entonces, existirá porque ya existe en la imaginación, y lo mismo sucede con el pasado, como deja claro Meruane al rememorar algunos objetos que habrían llegado hasta Chile desde la lejana Palestina: "Qué se hizo de lo demás, de las sábanas que colgaban de una cuerda en el jardín, del minúsculo elefante de marfil que mis tías aseguran me inventé porque ellas no lo recuerdan" (23).

En principio, pese a que ella misma hace ver que viaja a un país que oficialmente ya no existe, la imaginación está menos presente en la crónica de Jeftanovic. No obstante, el episodio más importante de su viaje a Sarajevo lo constituye el recorrido que hace del túnel que sirvió como una comunicación, durante la guerra, entre la ciudad sitiada y el exterior. En una crónica meramente periodística, la visita al túnel habría servido para narrar la guerra y las terribles carencias que vivió la ciudad durante el sitio. No obstante, en esta crónica literaria, Jeftanovic aprovecha el túnel como metáfora para sumergirse no en lo más profundo de Sarajevo, sino en su historia familiar. Más que comunicar la ciudad con el exterior, el túnel se convierte así en un túnel de tiempo que le hace rememorar a 
la escritora todos esos episodios familiares que le acabaron aportando algo de la identidad yugoslava.

Otro punto en el que las tres autoras manifiestan una continuidad y un contraste con la poética más ortodoxa del relato de viajes es con el uso de los paratextos. Tradicionalmente, los libros de viajes vienen acompañados de mapas, fotografías y subtítulos que remarcan la condición verdadera del relato. Las tres autoras mantienen esta tradición, pero la subvierten. Rimsky $(227,232)$ es quizás la que lo haga de forma más radical, por ejemplo, cuando en la segunda edición incluye fotografías de la primera edición que, a su vez, mostraban documentos (mapas y fotografías) que remitían al viaje, y que ella da por perdidos. De esta manera, Rimsky remarca que la escritura se alimenta del viaje, pero también y sobre todo de la misma escritura, y si el hecho narrado alguna vez sucedió y por lo tanto es verdad, no es porque lo pruebe una imagen o porque el itinerario pueda seguirse en un mapa, sino porque el viaje ya fue narrado una vez. Meruane, por su parte, al incluir la correspondencia que intercambió con el escritor que finalmente la recibió en Tel-Aviv, incluye la marca de borrado en las líneas más delicadas, como un guiño a la censura israelí o a la paranoia producida por las medidas de seguridad. Por último, Jeftanovic no incluye en su libro fotografías de los sitios más significativos que recorre, sino imágenes que dialogan con pasajes específicos del texto, lo que se enfatiza por la inclusión de pies de fotos que, de hecho, son citas extraídas del mismo libro. De esta forma, se crea un espacio comunicativo en el que el texto da pie a la imagen y viceversa, de la misma forma en que el viaje suscitó la escritura, y viceversa.

Las tres viajeras regresan sin nuevas certezas; si lo que planeaban era reafirmar su identidad o encontrar alguna prueba nueva sobre su pasado trasatlántico, el viaje puede verse como un fracaso. Naturalmente, no lo es: despojarse, de hecho, de una identidad tan circunscrita a un territorio político resulta liberador para las tres. Los tres libros pueden leerse como los testimonios de una renuncia, la de la herencia de los pesos políticos, y como una reafirmación, la de la reivindicación de que cada uno es consecuencia de un conjunto de decires y leyendas que alguna vez estuvieron anclados a un territorio. La memoria, entonces, se vuelve selectiva e incluso optativa y creativa: las tres viajeras imaginan y deciden de dónde proceden: Jeftanovic, de un país que ya no existe, Yugoslavia; Rimsky, de un país que fue arrasado y del que no queda nada, los pueblos judíos de Ucrania; Meruane, de un país que existió y que lucha por volver 
a hacerlo, Palestina. Pero, más allá de la problematicidad política de los tres territorios, las tres autoras reivindican un origen íntimo, afectivo, al que no se puede regresar, pero como los tres libros demuestran, al que sí se puede ir.

\section{Conclusiones}

Alguna vez la crónica de viajes tuvo una intención netamente informativa. Todavía hoy, algunos de los cronistas latinoamericanos más celebrados escriben para dar cuenta del presente de ciertas ciudades (como la serie de reportajes que a lo largo de 2019 Martín Caparrós está publicando sobre ciudades latinoamericanas en El País) o para describir cierto acontecimiento curioso (como Una historia sencilla, de Leila Guerriero, en el que narra un concurso de baile folclórico en un pequeño pueblo argentino). Villanueva Chang, editor de la peruana Etiqueta Negra, uno de los principales vehículos de difusión de la nueva crónica latinoamericana, es claro cuando describe la labor de los cronistas: "Un cronista narra una historia de verdad sin traicionar el rigor de verificar los hechos, pero con el fin de descubrir a través de esa historia síntomas sociales de su época" (590). Los tres textos analizados se alejan de esta intención informativa o divulgativa, sin abandonarla por completo, para concentrarse en un asunto completamente íntimo: la investigación acerca del propio pasado legendario. Por si fuera poco, renuncian en apariencia a descubrir síntomas sociales de la época, y se abocan a rastrear su propia historia familiar.

Esta contraposición con el objetivo tradicional de la crónica de viajes desata varias subversiones más a un género que, si bien es versátil, siempre se muestra inflexible en algunos aspectos, como el de la veracidad. Las tres autoras dejan entrar deliberadamente a la imaginación en sus textos, no para propiciar una lectura ficcional de ellos, sino para manifestar que - más cuando se trata de identidades nacionales, familiares y personales - ella es la que construye en buena medida la verdad. En consecuencia, el itinerario que siguen está trazado por los recuerdos ajenos, por los afectos propios y por las leyendas familiares, por lo que el viaje realmente recorre una geografía sentimental para la que los mapas solo son una mera aproximación. En este sentido, podemos leer la reivindicación de los afectos y el protagonismo del autor-narrador, en un género en el que suele ser relegado a la figura de mero testigo, como 
la respuesta en la crónica a la poética contemporánea en la que todas las variantes de la literatura del yo adquieren relevancia. Si hasta ahora la crónica literaria había sido vista como la subjetividad y estilización de una mirada, ahora se conserva este punto de vista, pero para observarse a sí mismo. Por supuesto, esta crisis del individuo puede trasladarse a una crítica social, lo que acercaría a estas crónicas a la crítica cultural, posibilidad defendida por Darrigrandi (“Crónica latinoamericana...” 138) en su análisis del género.

Para concluir, es conveniente señalar el papel que juega la ambigüedad en los tres textos. Incluso ahora, el propósito de la crónica de viajes es transmitirle al lector una realidad, en consonancia con la crónica modernista que, según Rotker (25), es la mezcla entre periodismo y literatura, mientras que los tres textos insisten en dejar más preguntas que respuestas, y más que certezas, suman restas. En lugar de encontrar, las tres viajeras pierden rastros, testimonios, verdades, lugares; podría afirmarse, incluso, que las tres crónicas narran un despojamiento y, al comprobar mediante el viaje que no hay verdades sobre todo cuando se trata de buscar la propia identidad, solo queda el sujeto desnudo, libre, listo para volver a partir en busca de nuevos orígenes que no existen. El viaje a la raíz acaba siendo la raíz del viaje, y dado que no hay hallazgos definitivos, las posibilidades siempre serán inagotables.

\section{Referencias bibliográficas}

Brangier Peñailillo, Víctor. “Construcción de alteridades subalternas en los testimonios de viajes de Benjamín Vicuña Mackenna. Apuntes para una 'lectura a contrapelo' en esta categoría de fuentes". Historia 396, no. 1, 2012, pp. 35-65.

Brintrup, Lilianet. "El libro móvil: viaje y escritura en algunos viajeros chilenos del siglo xix". Revista Chilena de Literatura, no. 42, 1993, pp. 57-64.

Casini, Silvia. "Luis Sepúlveda: un viaje express al corazón de la Patagonia”. Alpha, no. 20, 2004, pp. 103-120.

Darrigrandi, Claudia. “Crónica latinoamericana: algunos apuntes sobre su estudio". Cuadernos de Literatura, no. 34, 2013, pp. 122-143.

García Canclini. Culturas híbridas. Buenos Aires, Paidós, 2013. 
García, Victoria. “Del Che Guevara a Enrique Raab. Viajeros argentinos a la Revolución Cubana". Castilla. Estudios de Literatura, vol. 6, 2015, pp. 269-313.

Galgani Muñoz, Jaime. "Paseo escritural de Augusto d'Halmar durante la Primera Guerra Mundial en París”. Literatura y Lingüística, no. 38, 2018, pp. 77-101.

Guzmán Rubio, Federico. “Tipología del relato de viajes en la literatura hispanoamericana: definiciones y desarrollo". Revista de Literatura, no. 145, 2011, pp. 111-129.

Jeftanovic, Andrea. Destinos errantes. Barcelona, Comba, 2016.

Lindsay, Claire. Escritura contemporánea de viajes de América Latina. Bogotá, Instituto Caro y Cuervo, 2016.

Meruane, Lina. Volverse Palestina. México, D.F., Conaculta, 2013.

Pérez Villalón, Fernando. "Variaciones sobre el viaje: dos viajeros ejemplares (Mistral y Oyarzún)". Revista Chilena de Literatura, no. 64,2004 , pp. 47-72.

Poblete Alday, Patricia. "Hibridez y tradición en la crónica latinoamericana contemporánea: los textos de Rafael Gumucio”. Revista Iberoamericana, no. 254, 2016, pp. 185-198. “La crónica periodística-literaria contemporánea en Chile". Estudios Sobre el Mensaje Periodístico, vol. 20, no. 2, 2014, pp. 1165-1176.

Ramírez Errázuriz, Verónica. “Orientalismo y antioccidentalismo: discursos que enmarcan la representación del yo en el relato de viaje de Inés Echeverría (Iris)". Revista Chilena de Literatura, no. 95, 2017, pp. 149-176.

Rimsky, Cynthia. Poste restante. Buenos Aires, Entropía, 2016.

Rotker, Susana. La invención de la crónica. Buenos Aires, Fondo de Cultura Económica, 2005.

Saítta, Sylvia. Hacia la revolución. Viajeros argentinos de izquierda. Buenos Aires, Fondo de Cultura Económica, 2007.

Villanueva Chang, Juan. "El que enciende la luz. ¿Qué significa escribir una crónica hoy?”. Antología de crónica latinoamericana actual. Ed. Darío Jaramillo Agudelo. México, D.F., Alfaguara, 2012. 